\title{
Assessment of training needs of winemakers and management systems of the wineries in Armenia
}

\author{
Vardan Urutyan $^{1}$ and Anna Yeritsyan ${ }^{2}$ \\ ${ }^{1}$ ICARE Foundation, Director, 74, Teryan str., 0009 Yerevan, Armenia \\ ${ }^{2}$ ICARE Foundation, Research Director, 74, Teryan str., 0009 Yerevan, Armenia
}

\begin{abstract}
Armenia has been well known for wine production for many centuries. During Soviet times the industry was particularly specialized in wine, brandy and sparkling wine making. Nearly $25 \%$ of brandy produced in the Soviet Union was made in Armenia. After the independence in early 1990s, the industry as a whole collapsed and production volumes declined sharply. Wine industry also shrunk dramatically. During late 90 s and early 2000s the sector started to grow slowly. However, the main driver of the sector was brandy production. During recent years the volumes of wine production also started to slowly recover. However the wineries in Armenia still have a number of problems: technology and equipment in wineries need to be replaced; production and quality control systems do not correspond to the international requirements; there is a lack of specialists for key winemaking positions, such as wine technologist or laboratory specialist; there is a need for short-term and long-term training, since most of professionals that graduate from wine-related departments in higher or vocational education institutions do not possess necessary skills and practical experiences to contribute to the production process. The main goal of this research was to improve the perception of the experience, management systems and needs of winemaking companies in Armenia, as well as to identify training and technical assistance needs for winemakers. The focal point of this study was the winemakers' training needs assessment, as a result of which it is envisaged to develop and implement training programs in winemaking sector jointly with well known foreign universities. In the scope of the study Management Systems and Skill Assessment has been conducted and number of recommendations for improvement has been proposed.
\end{abstract}

\section{Study methodology}

During the study, all wineries operating in Armenia were visited and face-to-face interviews were conducted with the directors and wine technologists. As of October 2014, around 35 companies involved in wine production were identified in Armenia, but 5 of those were newly established and did not have any wine production yet. ${ }^{1}$ The ICARE research team contacted all those companies, but the number of responding companies was 27 . Two surveys have been conducted. The first one was aimed to identify the training needs in the wineries, reveal current situation and problems in the wineries. Main parts of the survey were: a) general information about the company, b) training needs assessment and c) the state of the sector and further development expectations.

\footnotetext{
${ }^{1}$ www . minagro. am states that there are 50 grape processing companies operating in Armenia. There are a few companies that produce only wine, the rest produce wine, brandy, vodka and fruit wines.

${ }^{2}$ International Professional Managers Association - http: // www. ipma.co.uk/management-competences.php. ${ }^{3}$ Discovery news, citing Journal of Archaeological Sciencehttp: //news.discovery.com/history/art history/winery-oldest-armenia-110111.htm
}

Within the scope of the second survey, Management Systems and Skills Assessment was implemented. This survey was conducted with the company manager or operating director and provided information about management practices and efficiency assessment across five components necessary for business development: Production, Innovation and Technologies, Strategic Management, Marketing and Sales, and Finance. Through 5-point Likert scale, the relative importance of each characteristic as well as the ranking of each category was shown. The survey components were adapted using a model called Management Competency Value Chain ${ }^{2}$ that reveals Management performance across seven areas of Management: Innovation Management, Strategic Management, Marketing Management, Financial Management, HR Management, Operations Management, and Management Information Systems.

\section{Sector background}

Grape wines were produced in Armenia for several Millenniums. The world's oldest winery was discovered on the territory of Armenia in 2011. ${ }^{3}$ It dates back to 4000 B.C. and proves that the tradition of wine making in Armenia is nearly as old as the country itself. During the last century wine production volumes in Armenia have increased drastically. It needs to be mentioned that after 


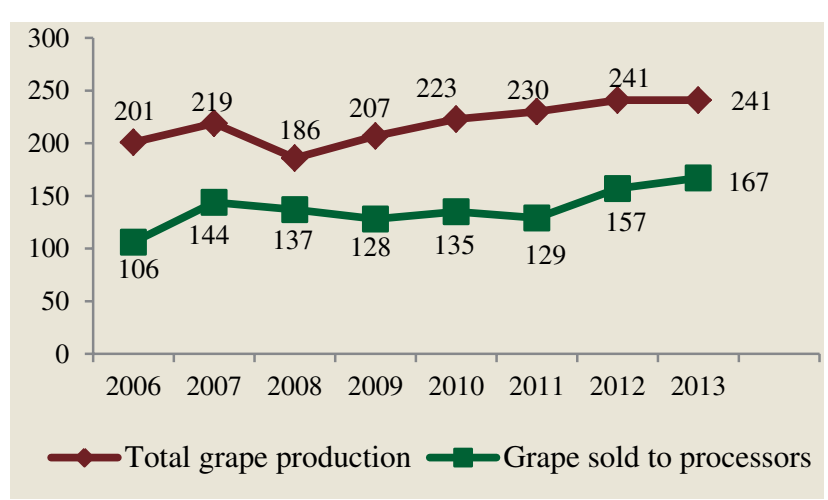

Figure 1. Dynamics of grape production and sales to processors.

1985 when the peak of grape production in Armenia was observed, there was a noticeable decline of grape production volumes mainly due to aging vineyards.

Prior to independence, 2 industrial unions, 3 large winemaking factories and 26 wine plants were involved in brandy and wine production ${ }^{4}$. According to the data of the RA NSS, during the first 7-8 years of independence, wine production decreased more than 30 times in the country, the production of champagne - more than 3 times, and that of brandy - 5 times. In late 1990's production of wine started to be rehabilitated, although in a small pace. During late 90 -s and early 2000 -s the sector started to grow slowly. However, the main driver of the sector was mainly brandy production. During recent years the volumes of wine production also started to recover. Exported wine and brandy are mainly supplied to the Russian market.

The grape/fruit wine and brandy sector in Armenia is one of crucial segments for economic growth and employment. The 2014-2025 development policy ${ }^{5}$ set by the Government of Armenia seeks to develop several sectors that will contribute to economic growth and poverty reduction. Private sector development, business environment improvement and vocational education are within the main focus of the policy. In particular 2010-2020 Sustainable Agricultural and Rural Development Policy prioritizes high-value added processing industries, such as wine production. ${ }^{6}$

Armenia has climate and soil characteristics that suit grape production. Main grape producing regions are Ararat Valley, Ararat Valley foothills, North-East of Armenia, Vayots Dzor. Over 83\% of grape production in Armenia is in Ararat and Armavir Marzes. Not surprisingly many processing plants are located in these two marzes to minimize transportation expenses and avoid grape fermentation in the transportation process. Grape production in the country has an increasing trend. Figure 1 shows that grape production volumes have increased from 186 thous. tons in 2008 to 241 thous. tons in 2013.

\footnotetext{
${ }^{4}$ A. Harutyunyan - Viticulture and winemaking in Armenia (2007) ${ }^{5}$ RA 2014-2025 Sustainable Development Strategic Program http: //www.gov.am/files/docs/1322 .pdf . ${ }^{6} R A$ Sustainable Agricultural and Rural Development Policy for 2010-2020. www. minagro.am .
}

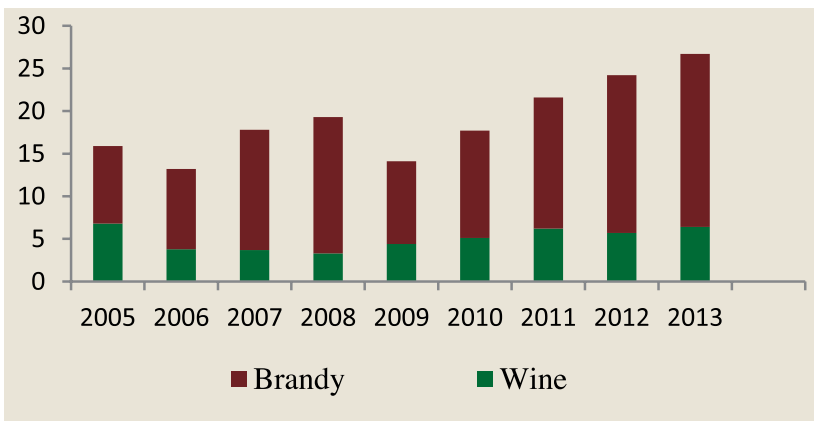

Figure 2. Wine and brandy production in 2006-2013 (mln.).

In 2007-2011, growth in the production volume was observed due to the increase in both local and foreign investments over the recent years. During the last few years, large investments were made in the winemaking sector, especially for purchasing progressive technologies and modernization of production processes. Areas under grape cultivation also increased during recent years. Some processors choose to have their own vineyards to be able to grow specific varieties of grape. This contributes to increased areas under grape cultivation.

Volumes of wine and brandy produced in Armenia have been showing a steady growth. There was a slump in production in 2009, which was an echo to financial crisis consequences, but from the next year on the increasing trends continued. Figure 2 shows the statistics on wine and brandy production from 2006 to 2013 .

The figure shows that brandy production nearly doubled during last five years. Wine production experiences a slower growth and has increased from 4.4 to $6.4 \mathrm{mln}$. liters in the last 5 years. Taking into consideration favorable Government policies for wine production, ${ }^{7}$ and the number of newly established wineries, it will be reasonable to assume that the volumes of wine production are expected to grow.

During recent years wine exports, as well as local wine sales have noticeably increased. Nevertheless per capita wine consumption is still very low. This fact is brought forward as one of the obstacles for wine industry development by EV Consulting in their study of the Armenian wine making sector. ${ }^{8}$ Wine imports dynamics over the last years is presented in Fig. 3.

Decline in import volumes from 2008 to 2009 can be attributed to post-crisis shocks that in countries like Armenia are experienced with a slight delay. After 2009 the imports have increased nearly 3 times and amounted to 717 thous. liters in 2011. It is interesting to note that during next two years imports of wine declined nearly two times. This can be explained by the increased consumption of local wine and by the fact that within last few years several Armenian

\footnotetext{
${ }^{7}$ Ministry of Economy and the Ministry of Agriculture of the RA with the support of USAID and EDMC "Food Processing Guide", page 21 (2014).

${ }^{8}$ EV Consulting "Armenian Winemaking Sector Assessment, Development Strategy and Action Plan” page 6 (2012).
} 


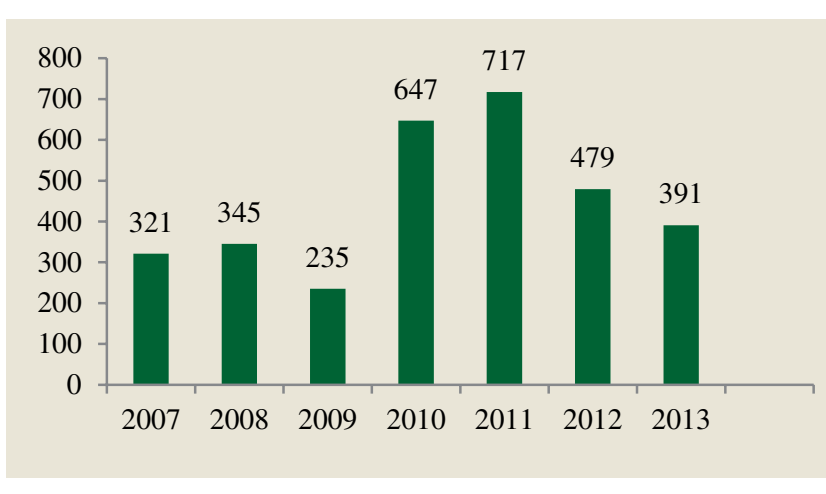

Figure 3. Wine Imports in 2007-2013 (000 lit.).

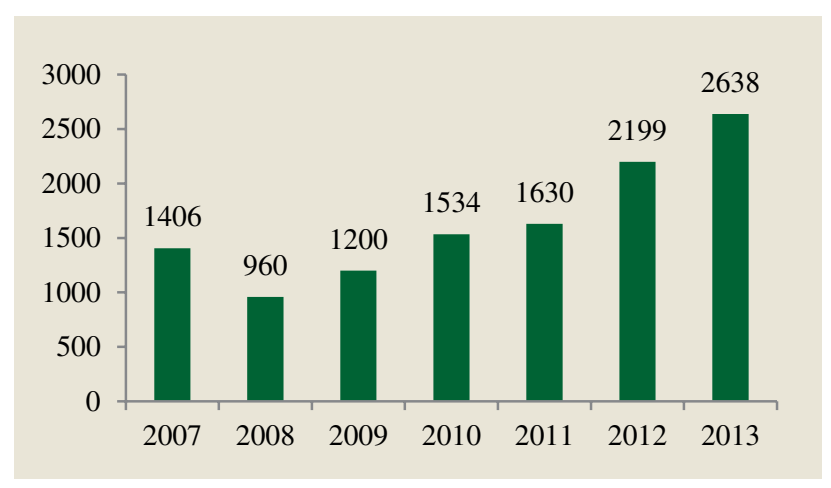

Figure 4. Wine Exports in 2007-2013 (000 lit.).

producers introduced wine varieties that have gained international recognition in the very short period of time. Armenian exports of wine (both grape and fruit wine) have been steadily increasing during the recent years. The volumes of wine exports have nearly tripled from 2008 to 2013. The monetary value of the grape and fruit wine export in 2013 comprised about $8 \mathrm{mln}$. USD of which $4.3 \mathrm{mln}$. USD was grape wine. These numbers are still expected to grow, since number of new producers had obtained wine production license during the last year and some of those are pure export-oriented.

The wineries in Armenia still have a number of problems. The production and quality management systems still do not meet to the international standards. Despite the investments made in the sector during the recent years, a large number of wineries continue using outdated technologies, which, undoubtedly, affects the quality of wine. However, this study is focused on one of the problems only - professional training of winemaking technologists.

\section{Study results}

\subsection{Situational assessment}

General description of winemaking companies: The Fig. 5 below shows that there are very few big scale wine productions in Armenia. About 52\% of companies surveyed had less than 20 people permanently employed in the winery and only $22 \%$ of those had more than 60 people

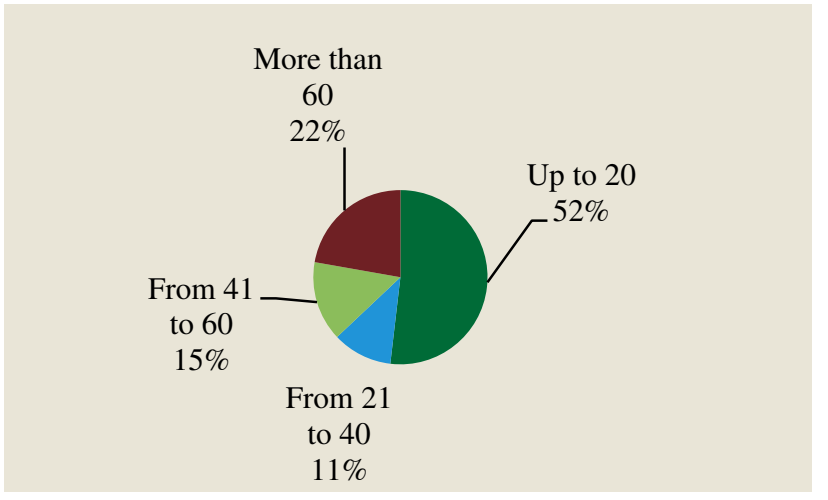

Figure 5. Distribution of companies by number of employees.

permanently employed in the company. Wineries usually hire some seasonal help during grape procurement period. Number of seasonal employees can be twice as much as number of permanent employees in the company.

The average winery capacity was about 7-8 times more than the actual production volumes. Almost $80 \%$ of companies surveyed export their production, be that a wine, brandy or vodka (Fig. 6).

For those who exported, the average share of exports was about $60 \%$ of company total production. 8 companies, i.e. roughly half of those who export wine, reported that they export more than $90 \%$ of the wine produced. It is a common practice that wineries may produce alcoholic beverages other than wine as well. Companies surveyed were producing four main groups of beverages: Wine, Fruit wine, Brandy, Sparkling wine and vodka. Apparently beverages produced by most of companies are wine and brandy. But only 10 out of 27 companies surveyed produce only wine (grape wine or fruit wine).

Increasing quantity and quality of wineries' production is the focal point of all companies and one of the priorities of the Government of Armenia in the strategic plan for the next decade. There are several obstacles companies face for achieving higher sales volumes and quality excellence (as mentioned by responding companies in Fig. 8).

About $63 \%$ of companies mentioned that they need more financial means, and over 55\% mentioned the need for better technologies and/or need for own laboratory.

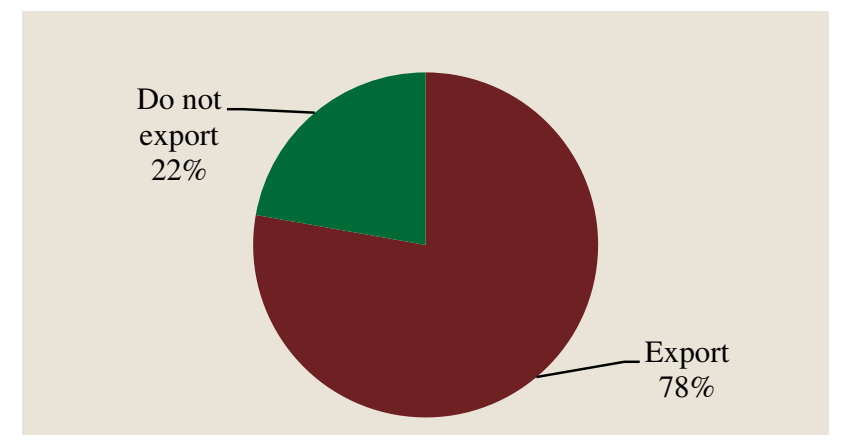

Figure 6. Share of companies that export their production. 


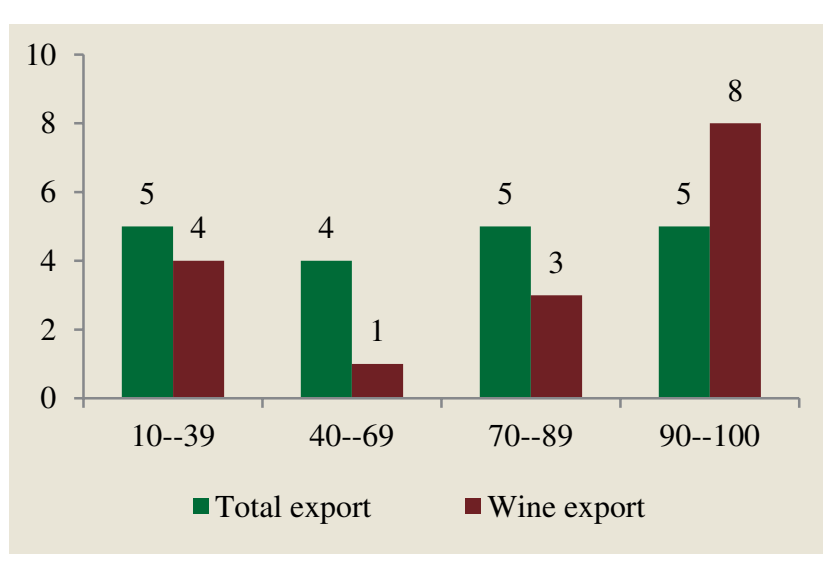

Figure 7. Exports as a share of total production.

$44 \%$ of companies believe that higher volumes and better quality will be achieved if there are improvements on the legislative and tax fields, and about one third of companies need skilled labor.

\subsection{Training needs assessment of wine makers}

There were total of 95 winemakers employed within 27 wineries that participated in the survey. Wine production plants mainly hire people through announcements. This option was selected by $76 \%$ of respondents. $48 \%$ mentioned that they hire people through personal connections; about $32 \%$ of surveyed Managers also mentioned that they hire people via company web-site and directly from Universities, and only $8 \%$ mentioned career centers.

Even though the companies figured out how to recruit employees, there are still some jobs that are hard to fill. Surveyed managers pointed out that there is lack of specialists with necessary skills nearly across all

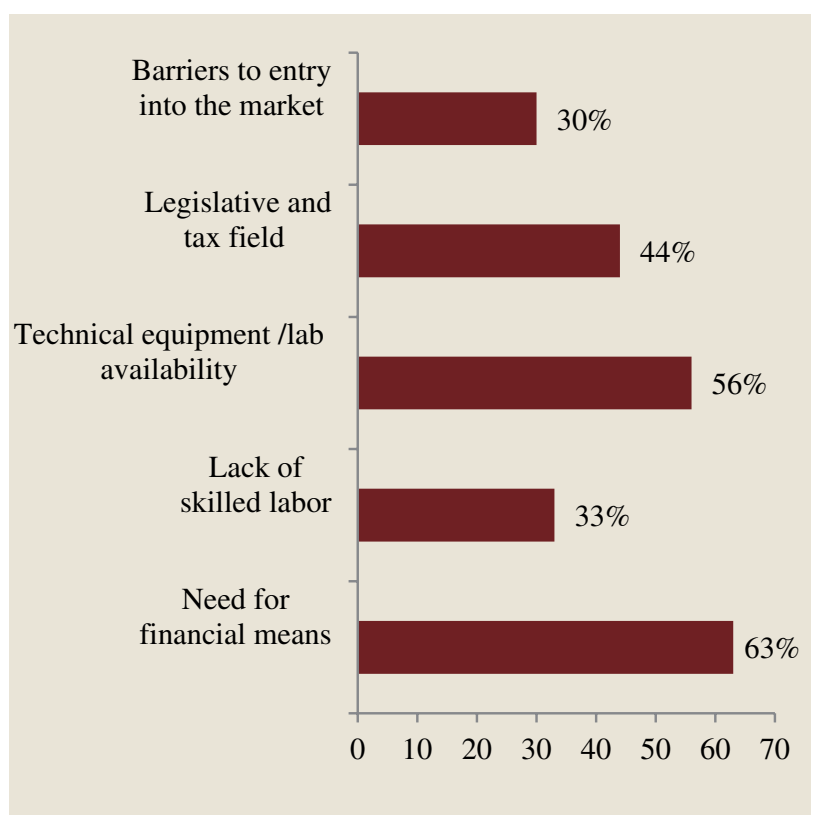

Figure 8. Main obstacles for increasing quality and quantity of wineries' production. problematic positions. In addition to that, they mainly mentioned that candidates do not have enough skills and experience, whereas for technical specialties such as mechanics specialty, the curriculums of educational institutions were not found appropriate. The discrepancy between educational curricula and skills needed in the production was mentioned for lab worker/biochemistry specialist, technologist and wine making specialties as well (see Fig. 9).

Many production managers were supporting an idea of promoting development of professional skills and capabilities of their employees. Only 3 out of the sample considered that there is no need for that. But when asked about trainings or seminars conducted during the last year for wine making specialists, 9 companies did not respond at all. $72 \%$ of companies that answered the question did provide trainings for their winemakers during the previous year, while $28 \%$ did not. The number of wine makers participating in the trainings is presented in Fig. 10.

If we look at the culture of conducting trainings by the size of the company, we can state that larger companies are more likely to conduct trainings for their employees. All companies in the sample with 60 or more employees are conducting trainings (either regularly or not always).

Secondary data analysis and desktop research revealed that in the wine sector there is a need for skilled labor, while the educational system in Armenia does not provide the necessary skills and knowledge to graduates.

In the light of this statement, wineries' management was asked to name possible ways to improve professional capacities of employees (several answers were allowed). More than $50 \%$ of managers mentioned that practical training in education curriculum needs to be strengthened. $37 \%$ of company officials mentioned also that there is a need in Armenia to organize educational programs in cooperation with international organizations. This will bring in the expertise and knowhow from leading universities and will promote application of the best experience across the world. Same share (37\%) belongs to the statement that educational programs need to be revised and adjusted based on market requirements. $26 \%$ of surveyed managers mentioned that relations need to be established between Armenian and International educational institutions and that the knowledge of academic staff preparing employees for wine industry needs to be upgraded.

The study identified the necessity of training and skill development for winemakers. The figure obviously shows that "Furnishing the laboratories with modern equipment and related specialists" is the most current for the wineries, and about $85 \%$ of wineries think that their winemakers need training or skill development on particular topics. The next important training field is "Availability and application of necessary equipment for the products produced" (77\%), followed by "Modern technologies used in production" (73\% think there is a need of training in this field) (see Fig. 12).

In addition to identification of training needs according to target fields, the research also revealed the priority areas in the wineries where winemakers need to be trained. The complete picture is provided below $(* 1=$ not important fields, 5 = primary fields).

The table shows that the wineries consider the following fields as the primary ones for their winemakers 


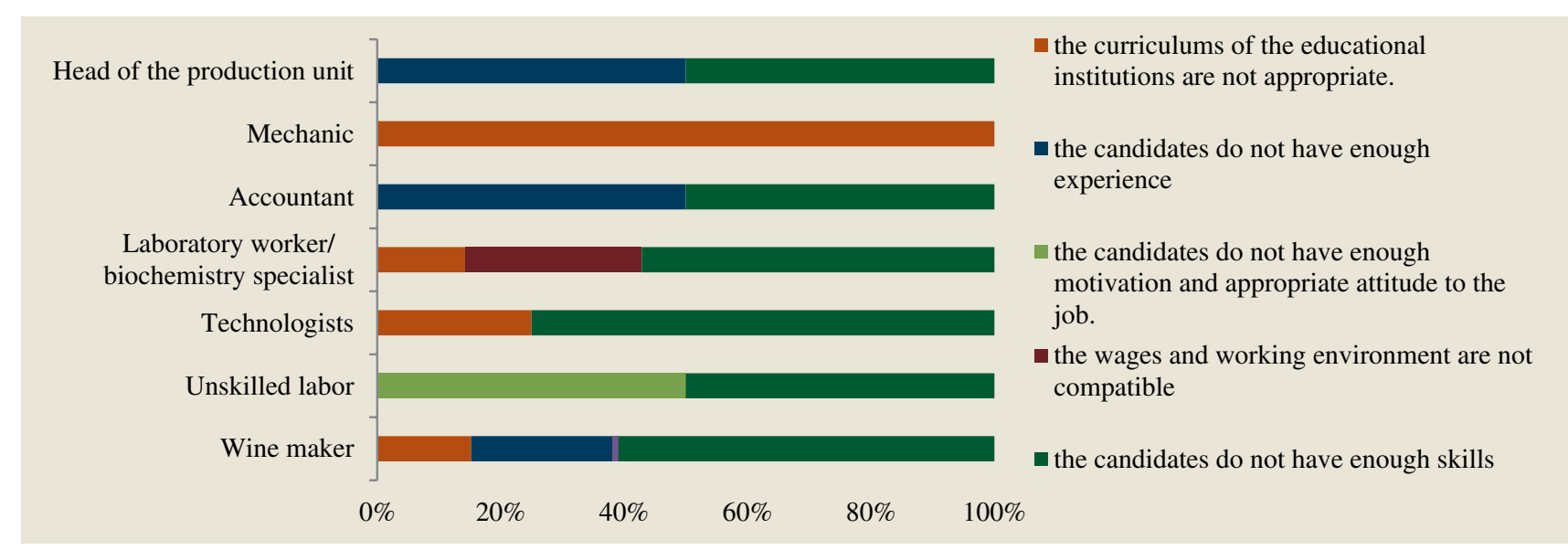

Figure 9. The positions that are hard to fill and reasons why.

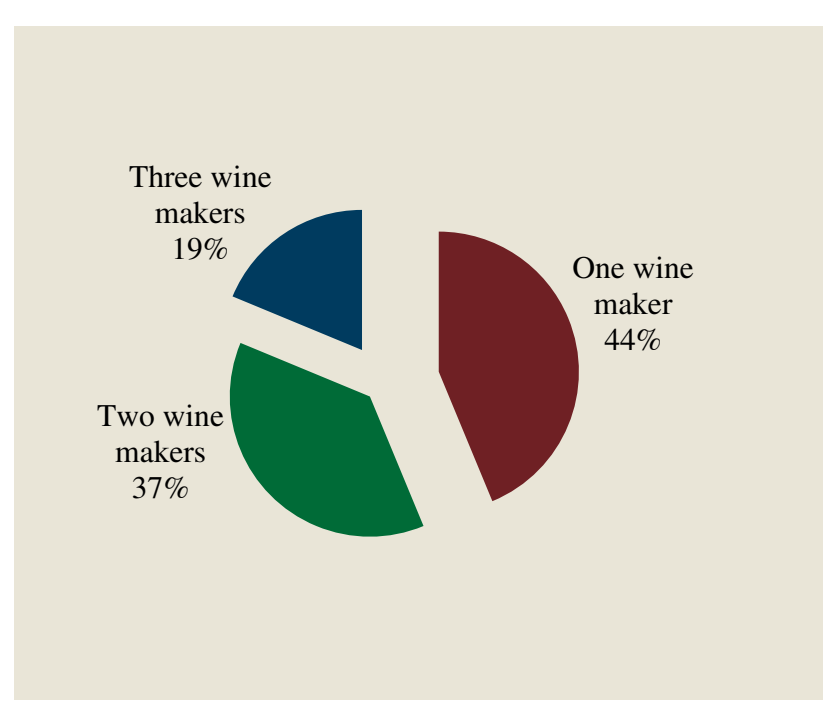

Figure 10. Number of wine making specialist who participated in trainings during the last year.

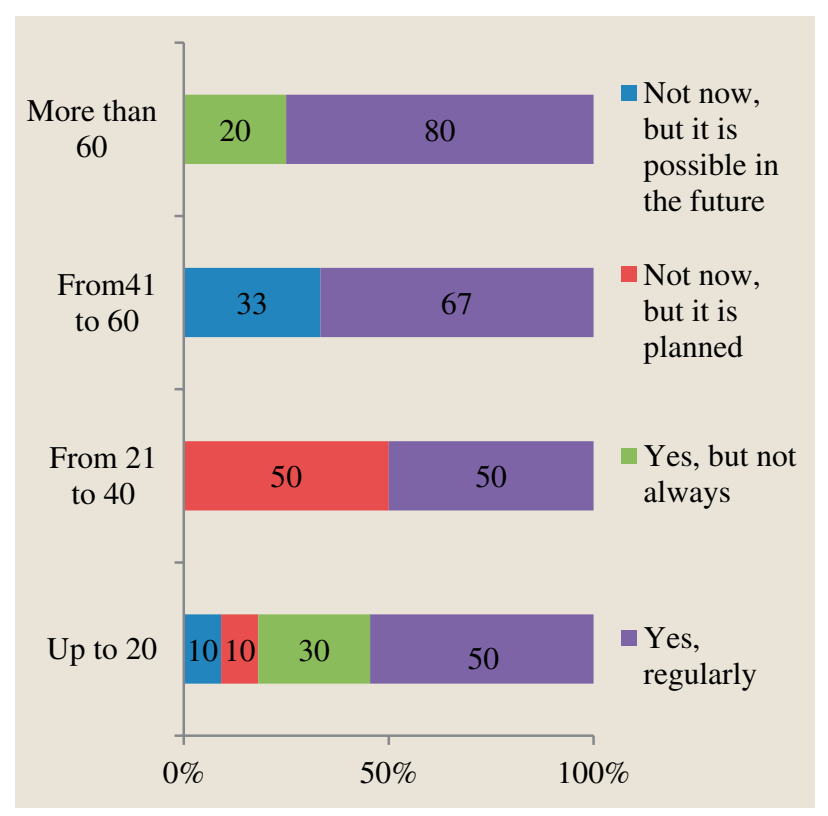

Figure 11. Trainings provided to employees by size of wineries.

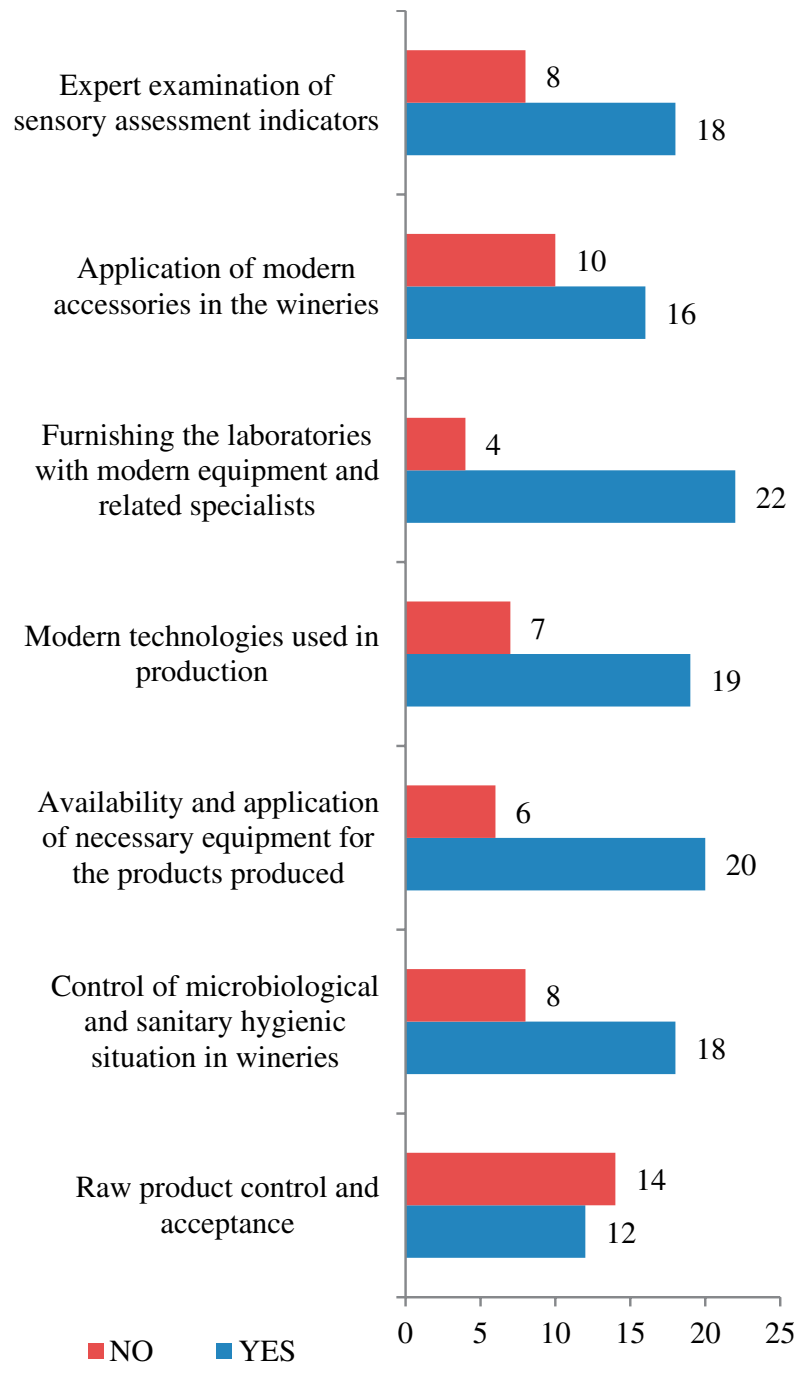

Figure 12. The need for training according to the target spheres. 
Table 1. Rating of training fields according to priority.

\begin{tabular}{|l|c|}
\hline $\begin{array}{l}\text { Target field of } \\
\text { training/consultancy }\end{array}$ & $\begin{array}{c}\text { Number of companies } \\
\text { that ranked 5 * }\end{array}$ \\
\hline Raw product control and acceptance & 8 \\
\hline $\begin{array}{l}\text { Control of microbiological and } \\
\text { sanitary hygienic situation in } \\
\text { wineries }\end{array}$ & 14 \\
\hline $\begin{array}{l}\text { Availability of equipment necessary } \\
\text { for the products produced and } \\
\text { application thereof }\end{array}$ & 12 \\
\hline $\begin{array}{l}\text { Modern technologies used in the } \\
\text { production }\end{array}$ & 12 \\
\hline $\begin{array}{l}\text { Furnishing of laboratories with } \\
\text { modern equipment and related } \\
\text { specialists }\end{array}$ & 9 \\
\hline $\begin{array}{l}\text { Application of modern accessories } \\
\text { in the wineries }\end{array}$ & 10 \\
\hline $\begin{array}{l}\text { Expert examination of sensory } \\
\text { assessment indicators }\end{array}$ & \\
\hline
\end{tabular}

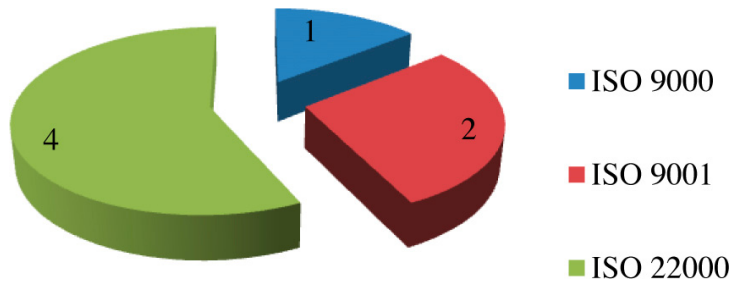

Figure 13. Wineries having food safety or quality management certificates.

a) Control of microbiological and sanitation and hygienic situation of the winery, b) Modern technologies used in the production, g) Availability and application of the equipment necessary for the products produced.

The best approach in implementation of trainings would be compiling pertinent thematic courses according to the priority and ranking of the target fields.

Sixty-four percent of the winemaking companies do not have any international certificate in the fields of food safety or quality management. Of those that do 4 wineries have ISO 22000, and 3 wineries have ISO 9000 or ISO 9001 certificates (presented in Fig. 13). The companies greatly valued inclusion of information on food safety standards, normative legal acts defining related safety

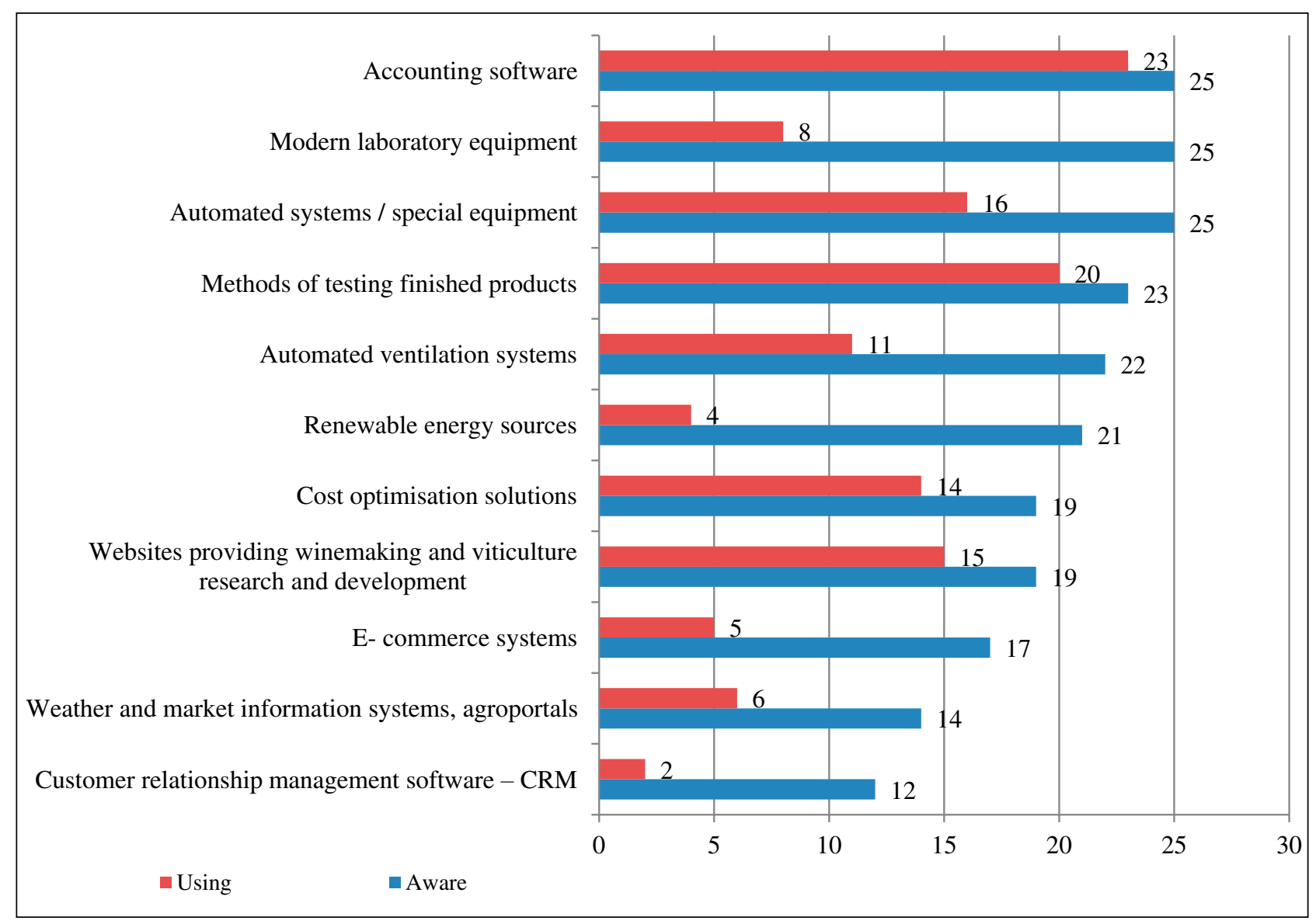

Figure 14. High technology solutions used in the wineries. 


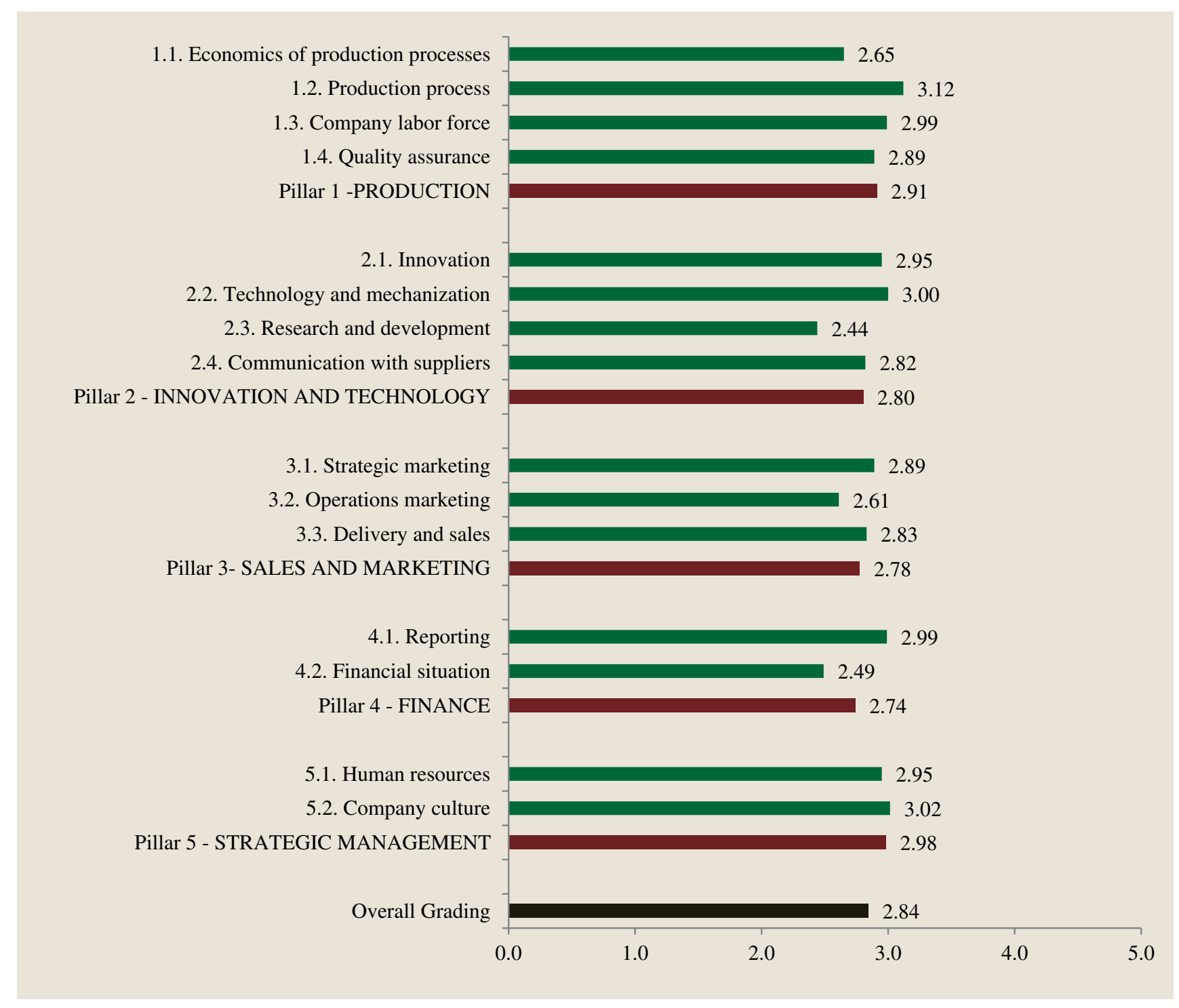

Figure 15. Wine sector Analysis (Management Systems and Skills Assessment).

indicators pursuant to the generally accepted international requirements, and HACCP in the training program.

The questionnaire also contained questions regarding the high technology solutions used in the wineries. We can state that accounting software have already been introduced in the winemaking companies. 85 percent of the companies have introduced accounting software (the main company providing such software is the Armenian Software), while the remaining companies are planning to introduce in the near future. Twenty-three companies are familiar with the methods of testing the finished products, of which 20 actually apply those methods in the wineries.

Nineteen companies are aware of websites providing winemaking and viticulture research and development, however only 15 companies use the information available in these websites. Agricultural portals providing information on weather conditions and market prices are familiar to 14 wineries, however only 6 of them are actually using these portals. Nearly all companies know about modern laboratory equipment, however only 8 companies actually have such equipment. The reason, perhaps, is the lack of finance.
Client relationship management (CRM) software, electronic sales systems are known to comparatively less number of companies, while they are used by only a few companies (see Fig. 14). Many wineries are envisaging in their short-term and long-term plans to purchase different equipment, high technology solutions, for which they need financial and technical assistance. The companies have the following needs in technological re-equipment or additional investment:

- Ion exchangers for wine processing

- Presses for grape acceptance-processing

- Automated systems of heat stabilization

- Membrane filters

- Automated production lines

- Barrels and Containers

- Laboratory devices, bottling lines, and others.

Part of the companies will step by step accomplish these investments on their own, while others are expecting technical (18\% of the companies) and financial $(20 \%$ of the companies) assistance. 


\subsection{Management systems and skills assessment}

The Management Systems and Skills Assessment survey consists of 5 pillars. The managers were asked to listen through the statement about the company operations and rate the statement according to the scale from 1 to 5 (where 1 means "completely disagree" and 5 means "completely agree"). Any ranking below 3 will indicate the existence of skills gap or inefficient use of a system. Each pillar is represented by separate sub-sections. Each green line represents average ranking of the sub-section, and the maroon line shows the pillar average rank (see Fig. 15).

The overall grading of the wine sector is 2.84 . The complete parameters and values are shown in Appendix. It is obvious that there is a need for improvement across all pillars.

Production pillar: Although it was mentioned that production capacities are not utilized effectively, winery managers have indicated that in general companies need more investments in the production process. Shortage of financial means leads to very low computerization while controlling movement of raw materials along the production, and while communicating with suppliers and buyers. Limited ability to conduct laboratory tests is also attributed to low investments in the up-to-date equipment. It was also mentioned that it is hard to outsource the necessary lab equipment or laboratory services, and leasing is not put into practice.

In general, most of the respondents agreed that production workers, such as engineers and laboratory personnel, need to have sufficient skills. They also indicated that production unit may not be well aware of market developments and demand, which implies that the production process is somewhat isolated.

The analysis of production pillar indicates that there is a need for technological improvement and equipment modernization in the wine industry. New labs need to be established and personnel have to be trained to be able to use the equipment.

Innovation and Technology pillar: It was mentioned that today market and business environment do not encourage for learning and innovation, therefore many companies do not see the need for conducting employee training and establishing information channels to learn more about innovations in the related industries. An alternative way of bringing in information and expertise could be collaboration with Universities with regard to research and development, but this partnership is not very valued by wineries either. In general, collaboration across the supply chain shows very weak performance: wineries do not consider technical assistance and advice to suppliers a necessary part of the mutually beneficial relationship.

It would be advised to improve communication with farmers and collaborate with research institutions and Universities for better understanding of market needs and demand.

Sales and Marketing pillar: The managers strongly support the opinion that market expansion is of great importance for the company, but on the other hand they also state that the company does not keenly practice mass marketing, does not implement periodical market analysis, and does not have well elaborated branding. So far this strategy is adopted by most of the companies in the winemaking industry, but the increased competition and higher production volumes are expected to draw more attention towards implementation of effective marketing activities. Within the problems associated with delivery and sales it was clearly mentioned that distributors are underpaid and have no incentive to promote the product.

It is strongly advised that companies in wine industry have separate marketing departments and actively practice the promotion of their product both locally and abroad. Further development of sales channels will provide a platform for wider distribution of the company product, and increased salaries of distributors will reduce employee turnover and decrease the costs of staff training.

Finance pillar: Another observation is that financial planning is underutilized in the winemaking industry. Many companies reported that they may not implement breakeven analysis and do not prioritize the importance of production cost reduction measures. On the other hand the management indicated that companies do not possess sufficient working capital and face constant difficulties for obtaining business loans.

The cost reduction mechanisms have to be enforced in all aspects of wine production. This would appeal to possible funders, and the chances of obtaining additional resources will increase.

Strategic Management pillar: The frequency of training conducted by wineries for their employees was rated below average. It was also noticed that companies are not heavily involved in providing additional educational programs for their employees.

Clearly there is a gap in knowledge and skills, and the need for additional training is identified within wine producing companies.

\section{Recommendations}

The study revealed that the winemaking industry in Armenia has taken an expansion path and is expected to develop more within the nearest years. Volumes of wine exports and production are going up and the number of wineries is increasing.

During the last years, new jobs have been created in the sector, however in future it will become an issue to prepare winemaking technologists ready to substitute the middle and old age winemakers who are currently working in the wineries. The wineries face also outflow of winemaking personnel, which means that winemaking technologists are not satisfied with their salaries, and they are ready to change their workplace even for a slightly higher salary. Most of the wineries also need additional winemakers. In addition to winemakers, the companies also need other specialists, for example, laboratory specialist, mechanic, etc.

Most of the winemaking companies believe that their winemakers need to periodically get trained and upgrade their knowledge. The research revealed the training and skill developments needs for winemakers according to target professional sectors. Most of the companies valued implementation of training courses for their winemaking technologists on the topics of "Furnishing of laboratories with modern equipment 
and related specialists", "Availability and application of proper equipment necessary for the products produced", and "Modern technologies used in the production". According to the priority, the following target fields for training were ranked the highest: a) Control of winery's microbiological and sanitation/hygienic situation, b) Modern technologies applied in production, c) Availability of the equipment necessary for the products produced and their application.

Therefore, the best approach for implementation of trainings will be compiling pertinent thematic courses according to the priority of the target sectors and the ranking, taking into account the training period and duration preferable for the companies.

The companies have strongly valued inclusion of information on food safety standards, normative legal acts defining related safety indicators pursuant to the generally accepted international requirements, and HACCP in the training program. Only a few companies had international certificates in food safety.

The level of high technologies used in the wineries is not so satisfactory. More than half of the companies do not use cost-effective solutions, which would help decrease the production cost and production-related and unrelated losses. The companies do not have sufficient means to shift to modern automated systems and acquire modern laboratories. The sector needs both technical and financial assistance.

Although there is a noticeable increase of investment in the winemaking sector, many producers still lack financial means for improving the technological base and replacing equipment in the production. Some wineries inherited antiquated machinery and huge facilities from soviet times and will never achieve $100 \%$ utilization. In addition to that, the old technologies are adversely affecting the quality of wine. So there is an obvious need for refurbishment or complete replacement of the existing machinery. There is also a need to increase the number of laboratories (some processors cannot afford their own laboratory and have to cooperate with other wineries to share their lab equipment). The cost reduction mechanisms have to be enforced in all aspects of wine production. This would appeal to possible funders, and the chances of obtaining additional resources will increase.

One of the main concerns raised by wineries' management is the low quality of input used in the winemaking, which needs to be addressed through helping farmers cultivate grape varieties that are most needed for high quality wine production. In general, collaboration across the supply chain shows very weak performance: wineries do not consider technical assistance and advice to suppliers a necessary part of the mutually beneficial relationship.

Management practices in many wineries need revision and enhancement. Quite a few production plants do not implement any research and do not have a marketing department. Not surprisingly many managers mentioned that there is very low awareness about their production both in the local and on foreign markets. In addition to this, wineries place very low importance to the implementation of financial analysis, such as breakeven analysis and reduction of production costs.

It is suggested that there be direct involvement of university staff in winery activities, such as research and development. As a result of this collaboration, the wineries will receive knowledge of market developments, and the university consultants will be aware of the skill requirements of the wineries.

\section{References}

[1] EV Consulting "Armenian Winemaking Sector Assessment, Development Strategy and Action Plan 2012", page 6

[2] A. Harutyunyan - "Viticulture and winemaking in Armenia" in Armenian language (2007).

[3] ICARE Foundation in collaboration with GIZ "Assessment of Training Needs and Skill Development of the Armenian Winemakers" (2013).

[4] Discovery news, citing Journal of Archaeological Science- http://news.discovery.com/ history/art-history/winery-oldestarmenia-110111.htm

[5] Food Processing Guide, 2014 Published by the Ministry of Economy and the Ministry of Agriculture of the RA with the support of USAID and EDMC, page 21 .

[6] International Professional Managers Association - http://www.ipma.co.uk/managementcompetences.php

[7] RA “2014-2025 Sustainable Development Strategic Program" http: //www.gov.am/files/docs / $1322 \cdot \mathrm{pdf}$

[8] www.armstat.am

[9] www.customs.am

[10] www.minagro.am 
Appendix. Management Systems Assessment Questionnaire average ranking.

\begin{tabular}{|c|c|}
\hline & Ranking (1-5) \\
\hline \multicolumn{2}{|l|}{ 1.1 Economics of production processes } \\
\hline The production capacities are effectively utilized by the company. & 2.89 \\
\hline $\begin{array}{l}\text { The management of the company shares opinion that the larger the production scale is, the more efficient the } \\
\text { operations are }\end{array}$ & 1.44 \\
\hline Breakeven analyses are implemented by the company & 2.59 \\
\hline Production planning is conducted at sufficient level. & 3.07 \\
\hline The company conducts planning related to procurement of raw materials, equipment and supplies. & 3.15 \\
\hline Measures to reduce production costs are of high priority in the company. & 2.41 \\
\hline Increase in production volumes is of high priority in the company. & 3 \\
\hline \multicolumn{2}{|l|}{ 1.2 Production process } \\
\hline The company has sufficient warehouse space and facilities. & 2.93 \\
\hline $\begin{array}{l}\text { The movement of raw materials and ready products along the production process is controlled by a } \\
\text { computerized system. }\end{array}$ & 2.63 \\
\hline Cleanness and the interior of the production space are at sufficient levels. & 3.19 \\
\hline Detailed control/analyses of purchased raw materials are implemented. & 3.44 \\
\hline The company has a systemized approach to control health and job security situation. & 3.22 \\
\hline $\begin{array}{l}\text { The company is in continuous search for new technologies related to improvement of production processes, } \\
\text { storage, and sales management. }\end{array}$ & 3.30 \\
\hline \multicolumn{2}{|l|}{ 1.3 The company labor force } \\
\hline Managers of the production process have a sufficient level of relevant skills. & 3.15 \\
\hline Technologists of the production process have a sufficient level of relevant skills. & 3.22 \\
\hline Engineers of the production process have a sufficient level of relevant skills. & 2.67 \\
\hline The above mentioned specialists work collaboratively. & 3.19 \\
\hline The production unit operates in collaboration with other divisions of the company. & 3.11 \\
\hline The production unit is well aware about marker demand. & 2.70 \\
\hline Engagement of new enologists is of high importance for the production process of the company. & 2.89 \\
\hline \multicolumn{2}{|l|}{ 1.4 Quality assurance } \\
\hline The consumers' demand towards quality is well-considered. & 3.40 \\
\hline The company has a quality control unit and the responsible personnel. & 3 \\
\hline The company has a quality control system in place. & 2.81 \\
\hline The company has specialists responsible for quality control (engineer, technologist, etc). & 3 \\
\hline The company has a threshold for defective produce (units of production, percentage). & 2.56 \\
\hline Increasing quality of wine is of high priority by the company. & 3.70 \\
\hline The company has a limited ability to conduct microbiological tests. & 2.44 \\
\hline The company has a limited ability to conduct chemical tests. & 2.22 \\
\hline \multicolumn{2}{|l|}{ 2.1 Innovation } \\
\hline The company introduced new products and used new technologies during the last five years. & 3.26 \\
\hline The company has a defined procedure for developing new products. & 3.07 \\
\hline The market and business environments continuously encourage for innovation. & 2.74 \\
\hline The company periodically conducts employee trainings and learning to encourage innovation. & 2.74 \\
\hline The company has established information channels to learn more about innovations in the related industry. & 2.93 \\
\hline
\end{tabular}




\section{Appendix. Continued.}

\subsection{Technology and mechanization}

The company highly values the importance of new technologies and uses new technologies in sales and production processes.

The company highly values the importance of new technologies and uses new technologies in accounting and 3 financial analysis.

The company highly values the importance of new technologies and uses new technologies in business communication with suppliers and buyers.

\subsection{Research and development}

The company has staff responsible for research and development.

The research and development activities are on average or above-average levels compared to other companies in the industry.

The company closely collaborates with the universities in implementation of research and development activities.

The company has the necessary laboratory equipment and fully utilizes those.

If needed, the company can easily outsource the necessary laboratory equipment or laboratory services.

Market needs are well-considered over the course of implemented research and development activities.

International certification is of high priority for the company.

\subsection{Communication with suppliers}

The main suppliers of raw materials are well aware about the product quality and technical requirements.

For majority of the suppliers collaboration with the company is an important aspect for their income creation process.

The company provides additional knowledge and skills to its main suppliers.

The company provides technical assistance to its main suppliers.

The company continuously expands the contract relationship with its main suppliers.

2.37

The collaboration with main suppliers is mostly sufficient.

\subsection{Strategic marketing}

A well-organized marketing team is in place.

Periodical market analyses are conducted.

It is well-understood who are the main buyers of the products.

The company practices mass marketing.

The competitors are periodically assessed and analyzed.

A well-elaborated branding strategy is in place.

Market expansion is of great importance for the company.

\subsection{Operations marketing}

The company has sufficient printed promotion materials.

The company has a special budget line for advertizing at final sales points.

The e-mail and TV marketing are practiced.

2.11

The company tries to be presented in both local and international fares.

The company is well aware about potential of export markets, as well as product specification requirements, customs procedures, and packaging requirements in those markets.

E-marketing is practiced.

Consumers' opinion and preferences are considered in product packaging.

The product labeling is done appropriately (information included, production site, ingredients, company contacts, etc.).

Communications and PR are implemented effectively. 


\section{Appendix. Continued.}

\begin{tabular}{|c|c|}
\hline \multicolumn{2}{|l|}{ 3.3 Delivery and sales } \\
\hline The sales unit and its staffing are in place. & 2.67 \\
\hline The distributors are paid according to their performance in sales. & 2.26 \\
\hline Price policy is flexible, depending on a buyer and its location. & 2.67 \\
\hline The sales channels are well-developed. & 2.44 \\
\hline The factor of competition is considered for the decision-making related to sales. & 2.93 \\
\hline The product/price mix is well-elaborated according to competitors' products and consumer preferences. & 3.07 \\
\hline Expansion of export quantities is of high priority for the company. & 3.44 \\
\hline \multicolumn{2}{|l|}{4.1 Reporting } \\
\hline Planning and budgeting are in place (sales, expected revenue, etc.). & 2.96 \\
\hline Budgeting methods are in accordance to market needs and company needs. & 2.85 \\
\hline $\begin{array}{l}\text { The budget is well-analyzed, and necessary modifications in budget or planned activities may take place } \\
\text { accordingly. }\end{array}$ & 3.19 \\
\hline Inflation is a substantial factor for operations and budgeting of the company. & 3.07 \\
\hline Currency exchange rates are substantial factors for company operations and budgeting. & 3.19 \\
\hline Market for the products is very volatile which highly affects the operations and budgeting. & 2.63 \\
\hline Electricity or/and natural gas prices highly affect the operations and budgeting. & 2.96 \\
\hline Micro and macro factors in the economy highly affect operations and budgeting of the company. & 2.70 \\
\hline \multicolumn{2}{|l|}{ 4.2 Financial situation } \\
\hline The company possesses sufficient working capital (financial means). & 2.59 \\
\hline Cash flow statement is prepared. & 2.78 \\
\hline Engagement of additional funds is easy (e.g. business loans). & 2.37 \\
\hline Engagement of additional funds is very costly. & 2.15 \\
\hline The company is engaged in leasing contracts for equipment. & 1.89 \\
\hline Cost reduction measures are a daily routine in the company. & 2.74 \\
\hline \multicolumn{2}{|l|}{ 5.1 Human resources } \\
\hline The HR department is well-staffed and is in place. & 2.96 \\
\hline Hiring is transparent and only those are hired who qualify to the given job vacancy requirements. & 3.22 \\
\hline The company has an environment where everyone has equal rights. & 3.22 \\
\hline The company provides training and additional educational programs to its employees. & 2.67 \\
\hline Both part-time and full-time work schedules are practiced. & 2.11 \\
\hline The company can hire employees who make effective teams and who complement one another. & 3.11 \\
\hline \multicolumn{2}{|l|}{ 5.2 Company culture and information about external environment } \\
\hline The company utilizes a well-defined organizational structure: horizontal or vertical. & 2.67 \\
\hline Team and group work are encouraged. & 3.26 \\
\hline Well-elaborated communication means with company stakeholders are utilized. & 3.15 \\
\hline Everyone in the company understands the responsibilities and the work to be done. & 3.15 \\
\hline Each employee realizes the accountability to the supervisor for the work implemented. & 3.22 \\
\hline $\begin{array}{l}\text { The company is aware about business development projects implemented by international organizations in } \\
\text { Armenia (the EU and US -funded projects, etc.). }\end{array}$ & 2.48 \\
\hline The company is prepared for international competition. & 3.04 \\
\hline
\end{tabular}

